\title{
Environmental pediatrics: an emerging issue
}

\author{
Patricia M. Valenzuela, ${ }^{1}$ M. Soledad Matus, ${ }^{2}$ Gabriela I. Araya, ${ }^{2}$ Enrique Paris ${ }^{3}$
}

\begin{abstract}
Objective: To review the most relevant articles regarding environmental pediatrics, its potential effects on health, and especially its advances in prevention.

Sources: A literature search was conducted using MEDLINE/PubMed and SciELO databases. Articles from 1990 to 2010 were reviewed, in addition to book chapters related to environmental pediatrics.

Summary of the findings: There is a significant variety of factors that make children highly vulnerable to environmental hazard exposure, which are mainly associated with children's comparatively greater consumption of water, food, and air in relation to body weight. According to the World Health Organization, every year more than 3 million children under the age of 5 die because of environment-related conditions. Approximately 30 to $40 \%$ of pediatric diseases are related to environmental factors. Children are constantly exposed to various environmental health hazards, among which the following stand out: contaminated water, lack of adequate sanitation facilities, air pollution, disease vectors, chemical hazards, injuries, and accidents.

Conclusions: Nowadays, pediatricians are challenged to address environmental pediatrics health care needs. The pediatric health history needs to be more comprehensive by adding pointed questions to help identify potential environmental risks. Awareness and understanding of the noxious effects of various environmental conditions and knowledge of the related prevention measures will result in timely and adequate interventions that will improve our children's health and development.
\end{abstract}

J Pediatr (Rio J). 2011;87(2):89-99: Pediatrics, environmental health, child, hazardous substances, prevention, environmental exposure, environmental medicine.

\section{Introduction}

According to the World Health Organization (WHO), environmental health encompasses all those aspects of human health, including quality of life, which are determined by physical, chemical, biological, social and psychosocial factors. It also refers to the theoretical and practical application of measures to assess, correct, control, and prevent environmental factors that may adversely affect the health status of present and future generations. ${ }^{1}$

There is a large variety of factors that make children highly vulnerable to environmental hazards. Among those factors is the fact that, compared to adults, children drink more water, eat more food, and breathe more air in relation to their body weight. Therefore, children suffer a substantially greater exposure to toxics than adults do. Additionally, the hand-mouth behavior and the fact that children live and play close to the floor increase even more their exposure to environmental hazards. ${ }^{2}$

Vulnerability of children to environmental factors such as those just mentioned makes environmental pediatrics a key issue for preventing or mitigating some of the risk factors.

1. MD. Assistant Professor, Department of Pediatrics, Pontificia Universidad Católica de Chile (PUC), Santiago, Chile.

2. Medical student, School of Medicine, PUC, Santiago, Chile.

3. MD. Associate professor, Department of Pediatrics, PUC, Santiago, Chile. Director, Centro de Información Toxicológica y de Medicamentos (CITUC), PUC, Santiago, Chile.

No conflicts of interest declared concerning the publication of this article.

Suggested citation: Valenzuela PM, Matus MS, Araya GI, Paris E. Environmental pediatrics: an emerging issue. J Pediatr (Rio J). $2011 ; 87(2): 89-99$.

Manuscript submitted Oct 06 2010, accepted for publication Dec 152010.

doi:10.2223/JPED.2079 
According to the WHO, every year more than 3 million children under 5 years of age die because of environmentrelated causes and conditions. ${ }^{3-5}$ Forty percent of such deaths are related to the lack of potable drinking water. ${ }^{6}$ Moreover, $30-40 \%$ of the diseases affecting children, such as respiratory and gastroenterological conditions, tumors, and malformations, are associated with environmental factors. 5,7 In the developing world, the most common environmental diseases are diarrhea and lower respiratory tract infections, while allergies and asthma are the most prevalent in developed countries. ${ }^{8}$

It is critical to develop behaviors that enable the prevention or reduction of diseases, disabilities, and injuries related to the indoor home environment, because children spend more than $90 \%$ of their time indoors. $2,8,9$

Environmental pediatrics has developed a series of measures intended to prevent and/or mitigate those diseases. One of these measures has been the removal of lead from gasoline and paint, which has had a major impact on reducing lead levels in the population. ${ }^{3}$ Also, other measures include the creation of the first pediatric environmental health specialty units (PEHSU) in the United States in 1998, then in Canada, Europe, and some Latin American countries. PEHSUs are centers specialized in the diagnosis, treatment, research, teaching, and prevention of environmentally-related diseases. ${ }^{6,10-12}$ These units have helped to address the gap in the knowledge of health care providers about environmental pediatrics.

Additionally, in the United States, as well as in other countries, there are governmental agencies responsible for controlling and preventing diseases related to the environment. ${ }^{13}$ Government health authorities should emphasize the importance of maintaining a safe environment for children, and include the reduction of environmental hazards and the promotion of healthy habits, education, and permanent surveillance in their policies.

Therefore, a review of the available literature addressing environmental pediatrics is a priority, in order to communicate and spread knowledge among pediatricians and other health professionals. The present review emphasizes the importance of environmental pediatrics, while summarizing the prevention behaviors advocated by environmental pediatricians for managing the environment.

\section{General household hazards Water}

Water is essential for life, and everyone should have access to a satisfactory water supply, characterized by being sufficient, innocuous, and accessible. Today, it is recognized that water is not an unlimited resource, and that the available fresh water on Earth is only $2.5 \%$ of the total water available. Consequently, the protection of water sources is a subject of global concern. ${ }^{14}$ Worldwide, 1.1 million people lack safe water access, and 2.4 billion lack basic sanitation services. ${ }^{15}$ It has been demonstrated that increasing safe water access may provide tangible health benefits ${ }^{16}$ by reducing to $80 \%$ disease and mortality rates due to serious conditions related to safe water deficits. ${ }^{14}$

Infants, toddlers, and immunosuppressed individuals have a greater risk of waterborne diseases. For this reason, children should always ingest potable drinking water, which does not entail any significant health risk when consumed over the whole lifespan. ${ }^{16}$ In cases of having no access to potable water (therefore ignoring the water quality or its origin), there are many available treatments to reduce pathogens, thus improving water quality and safety. The most effective treatment is to boil the water. Another treatment is chemical disinfection with chlorine or iodine, which kills bacteria, some viruses, and some protozoa, but does not eliminate Cryptosporidium cysts. It is important, after this water treatment measure, to use carbon filters to remove excess chlorine. There are also portable water filtration systems, such as ceramic filters and carbon block filters. In case of cloudy water, it should be first clarified by decantation, sedimentation, and filtration before treatment. ${ }^{16-18}$

Parents of children with severe immunosuppression should take additional precautions, such as boiling drinking water, to kill microorganisms normally present in water that do not affect the general population, but may harm immunosuppressed children. ${ }^{16}$

Among the effects attributed to unsafe water supply and to inadequate sanitization are various diseases like diarrhea, intestinal parasite infestations, malnutrition, anemia, failure to thrive, and also arsenic and pesticide intoxication, among others.

\section{Environmental air pollution}

Household air pollution is determined by outdoor air pollution, indoor sources of pollution, the characteristics of the building, and the habits of the residents. ${ }^{2}$ It has also been proven to be the main cause of upper respiratory tract infections, causing more than 2 million deaths every year among children under 5 years of age.

Half of the population worldwide cooks and generates heating with solid fuels such as wood, agricultural waste, and coal, which result in a great burden of exposure to pollutants for children. ${ }^{19}$ Moreover, appliances used for heating are usually not in good condition, thus increasing production of carbon monoxide ( $\mathrm{CO})$, nitrogen dioxide $\left(\mathrm{NO}_{2}\right)$, and particulate material.

$\mathrm{CO}$ is a colorless, odorless and tasteless toxic gas, and is produced by the incomplete combustion of carbon-based fuels. ${ }^{19,20}$ The most common source of CO exposure is smoke inhalation from wood and coal fires, motor vehicle exhaust systems, tobacco smoke, and faulty or improperly vented combustion appliances like stoves, heaters, boilers, 
and furnaces. If $\mathrm{CO}$ is inhaled, it diffuses across the alveolar-capillary membrane, and can be measured by the carboxyhemoglobin ( $\mathrm{COHb}$ ) level in the bloodstream. $\mathrm{CO}$ has 240-270 times greater affinity for hemoglobin than oxygen; therefore, $\mathrm{CO}$ inhalation significantly reduces blood oxygen carrying capacity. ${ }^{19} \mathrm{CO}$ intoxication results in tissue hypoxia affecting multiple organ systems.

Normal levels of $\mathrm{COHb}$ are $1-3 \%$ in non-smokers, and $3-8 \%$ in smokers. Concentrations above normal levels can cause significant health effects in sensitive individuals. ${ }^{20}$ There is no direct relationship between the severity of the disease and $\mathrm{COHb}$ levels; however, at levels lower than $10 \%$, the patient is asymptomatic, and, at $30 \%$ or higher levels, there is always the presence of signs and symptoms. 20,21

Reducing CO exposure is especially important, since it may be fatal. ${ }^{22}$ The gas initially produces fatigue and somnolence. As its concentration increases, headache, dizziness, confusion, disorientation, and impairment of consciousness may occur. Frequently, irreversible injuries and even death may result; thus, prevention remains crucial. 22

To prevent $\mathrm{CO}$ poisoning, it is necessary to prevent exposure to known sources of the gas. Furnaces must be installed outside the house, in a place with proper ventilation. In cases where this type of installation is not possible, forced-air furnaces should be used, and rooms should have good ventilation. ${ }^{23}$ Moreover, CO detectors are recommended, in order to prevent unintentional $\mathrm{CO}$ related deaths. These detectors are designed to measure the amount of $\mathrm{CO}$ over time and to trigger an audible alarm when dangerous levels of $\mathrm{CO}$ are reached. If $\mathrm{CO}$ detectors are used properly, they provide users with early detection of the potential risk and adequate warning to safely ventilate or evacuate the area. ${ }^{20}$

The ideal recommendation would be to use clean fuels (e.g., natural gas, electricity) and to encourage correct use and periodic maintenance of appliances, in order to optimize their safe operation. However, public implementation of these recommendations in the near future remains improbable. Therefore, strategies to improve home ventilation have been developed to decrease mortality due to CO-related causes. ${ }^{24}$ Moreover, the Chilean Medical Association (Colegio Médico de Chile), together with the Chilean Association of Engineers (Colegio de Ingenieros de Chile), created a proposal for the development of energy on both a sustainable and safe basis, in which eolic, tidal, solar and hydrogen energy are used, in addition to other less diversified energies, such as hydropower and geothermal plants ${ }^{25}$. These types of energy source will certainly replace solid fuels someday.

Cigarette smoke is the most important indoor air pollutant. The particulate pollutant concentration can be two to three times higher in smokers' homes relative to non-smokers' homes. ${ }^{26}$ In developing countries, 30-50\% of the population are smokers, with a higher percentage in urban than in rural areas. ${ }^{19}$ Tobacco contains more than 4,000 chemical compounds, many of which are toxic. ${ }^{26}$ Moreover, it contributes particulate matter, CO, ammonia, nicotine, and carcinogenic substances to the smoker and to the environment. ${ }^{19}$

Every year, 5.4 million people die of tobacco-related conditions. ${ }^{27}$ Of these, $37 \%$ are passive smokers (i.e. nonsmokers living in a smoker's environment). In Chile, $57 \%$ of the children are passive smokers. ${ }^{28}$ They are at greater risk of suffering eye and nasopharyngeal mucosa irritation, and also have a greater incidence of lower respiratory tract infections, cough, wheezing, and acute otitis media. Additionally, they are more likely to develop neurological impairment, behavioral disorders, some cancers, and cardiovascular diseases in their adulthood. ${ }^{28}$ For this reason, encouraging quitting tobacco use by adults is a key issue. ${ }^{29}$

Children and adolescents who smoke are more likely to develop lung cancer, chronic obstructive pulmonary disease, and cardiovascular diseases later in life. Also, children of smoking parents are more likely to smoke in adulthood, and tend to start this habit during adolescence. ${ }^{19}$ Children whose mothers smoked during pregnancy show low birth weight, decreased lung function, and predisposition to recurrent wheezing during infancy. ${ }^{19}$

There are cost-effective measures that can achieve significant decrease in tobacco consumption. One of the most effective strategies is promoting public policies aimed at the general population, such as the prohibition of direct and indirect tobacco advertising, increase in taxes and prices of tobacco, creation of smoke-free public places and workplaces, as well as visible and clear health-related messages on cigarette packages. All these strategies have been adopted by the WHO to control and reduce tobacco consumption. ${ }^{30}$ Pediatricians, gynecologists, general practitioners, and health professionals should educate parents, family members, and patients about the negative effects of tobacco. ${ }^{19}$

Among other contaminants, building materials represent a significant hazard to children. Asbestos may impair lung function. ${ }^{2}$ Cement, wood preservatives, and volatile organic compounds released by paints, resins, household cleaning agents, among others, may cause ear irritation, as well as eye and nasal mucosa irritation; moreover, they may increase the risk for respiratory infections, particularly in children and people with pre-existing chronic lung diseases.

\section{Lead}

Lead is one of the most toxic hazardous substances for humans. Children are at especially high risk of lead exposure, because their normal hand-to-mouth behavior brings some lead-contaminated dust to their mouths. Furthermore, children easily absorb lead into their growing 
bodies. Lead poisoning is a preventable disease which has changed its clinical manifestation over time. ${ }^{31}$ Classically, a variety of symptoms such as abdominal pain, vomiting, constipation, and muscle weakness were present in lead poisoning cases. Additionally, lead poisoning may cause anemia, gum lesions, oligospermia, interstitial nephropathy, hypertension, polyneuropathy, behavioral disorders, mental retardation, and seizures, among others.22,32 Currently, lead poisoning presents with a clinical feature of subtle diminished intellectual capacity. ${ }^{31}$

The main sources of lead are in deteriorating lead-based paint, car batteries, fuel, and mining, but also in some plastics, cosmetics, some ceramic pottery glazes, and, of course, water circulating through plumbing made with lead or lead solder. ${ }^{2}$

Lead has no beneficial role in human physiology. The substance can be absorbed through different pathways; the oral tract is the most frequent in children, but it can also be absorbed through inhalation or transcutaneously. Lead binds to erythrocytes and is distributed through the blood, accumulating in soft tissues and/or bones. Acute poisoning, with the symptoms previously described, is rare, as opposed to chronic exposure to low levels of lead, which manifests effects in cognitive and behavioral areas. ${ }^{31}$

Lead poisoning diagnosis is performed clinically and by laboratory tests. Currently, childhood lead toxicity is defined as a blood lead concentration greater or equal to $10 \mu \mathrm{g} / \mathrm{dL}{ }^{33}$ It is also possible to find changes in long-bone radiographs showing increased calcium deposits in the metaphyseal region. Moreover, abdominal radiograph may show radiopaque material in the intestine. ${ }^{33}$

One in 40 American children living close to large highways has blood lead levels greater than $10 \mu \mathrm{g} / \mathrm{dL} .{ }^{34}$ The importance of primary and secondary prevention, with a strong emphasis on environmental management, is crucial in such cases.

The most important part of the treatment is to identify the lead source and remove the patient from the contaminated environment. ${ }^{33}$ In addition, there is the lead chelation therapy, which should not be performed if the blood lead levels are lower than $20 \mu \mathrm{g} / \mathrm{dL} .{ }^{31}$

The use of lead in paints and school supplies was banned in Chile in 1996. However, lead is present in old buildings, demolition products, car batteries, radiators, and dumpsites. Children or their relatives may have access to such contaminated products; therefore, management of child's environment is critical.

There are multiple examples of environment mishandling both in Chile and abroad. During the eighties, in Arica, a metal processing company dumped 21 tons of mining waste; subsequently, while the city was growing, multiple housing units were built in the surrounding areas. The result was 12,000 children and adults affected over the years. For that reason, various measures were undertaken to decrease the impact of such a deleterious environmental situation, which included toxic waste removal as well as medical assessment, treatment, and relocation of the affected population.

\section{Household allergens}

Dust mites, furry pets, and mold are known as the most important household allergens. These allergens are closely associated with allergic reactions, bronchial asthma, allergic rhinitis, and atopic dermatitis. ${ }^{2,35}$ Furthermore, environmental dampness may promote growth of mold, which could trigger or perpetuate allergic rhinitis.

After pollen, dust mites are the second cause of respiratory allergy. ${ }^{35}$ The house-dust mite (Dermatophagoides) impact increases especially in spring and summer, when the weather is warmer. The mite may not seem to be a problem for non-allergic individuals, but, together with the increasing diversity of other allergens, normal exposure to mites can trigger allergic symptoms in people who have already been sensitized. ${ }^{35}$

The main reservoirs for mites are carpets, pillows, soft toys, bedding, and mattresses. Dust mite exposure occurs either by proximity of the nasopharyngeal mucosa to mite reservoirs or by the increase in airborne antigen during house cleaning. 36

There are some basic measures targeted to decrease dust mite exposure. Although all patients require education about preventive measures for allergies, this is especially important for patients at risk for allergic disease, particularly in cases that include family history of asthma, atopy, or specific allergies. ${ }^{19}$ One of the most important avoidance measures is to use allergen-impermeable covers around pillows, mattresses, and decorative pillows. Moreover, the bedding should be washed weekly in hot water with temperature over $54.4^{\circ} \mathrm{C}$, since this temperature kills most mites. ${ }^{37}$ Another specific measure is to remove carpeting, as it is one of the major sources of mite antigen. Although the application of acaricide agents may reduce the antigen level on carpeting, many experts no longer recommend it, because it is less effective than removing the carpet. 35,36

Mold is more frequent in household areas with high humidity, especially in basements, crawl spaces, kitchens, bathrooms, on ground floors, or in air conditioner condensers. ${ }^{36}$ Some studies have suggested an association between the presence of mold in the house and asthma symptoms. ${ }^{36}$ For mold eradication, it is necessary to remove moisture from the house, decrease the amount of water vapor in the bathroom, repair leaks, use exhaust fans while cooking, increase air flow, change furniture position from time to time, clean mold with detergent, eliminate indoor organic sources, among others measures. ${ }^{38}$ The use of dehumidifiers may reduce ambient humidity, but it does not effectively reduce the growth of molds on surfaces. ${ }^{38}$ 


\section{Food}

There are more than 200 foodborne diseases. In developing countries, microorganisms transmitted through food are the cause of $70 \%$ of the cases of diarrhea. ${ }^{39}$

There are five keys to food harmlessness: 1 ) keep hands and food preparation surfaces clean; 2) separate raw from cooked food, and also the utensils used for cooking from those used for serving; 3) cook food fully until it reaches $70{ }^{\circ} \mathrm{C}$; 4) keep food at safe temperatures below $5{ }^{\circ} \mathrm{C}$ and above $60^{\circ} \mathrm{C}$; and 5) use potable drinking water and safe raw materials: fruits and vegetables washed with drinking water, and also pasteurized milk. ${ }^{40,41}$

It is worth mentioning that infection by vibrio parahaemolyticus has been among the most common infections reported in recent decades. This infection is caused by an enteric bacterium that normally lives on the coastline of the Pacific Ocean, especially on the coast of Japan, Chile, New Zealand, Canada, Australia, and the United States, producing a self-limited enteritis that results in vomiting and diarrhea and lasts 3 days. 42,43 This infection is acquired by ingesting raw or poorly cooked seafood or due to cross contamination. Prevention may be implemented by cooking seafood for at least 15 minutes at $70{ }^{\circ} \mathrm{C} .44$

Another foodborne disease is caused by the algal bloom, usually called red tide. Red tide is an annual natural phenomenon characterized by an abnormal change of water color and that occurs on the coastline of the Pacific Ocean, on the Florida coast, and in the Gulf of Mexico. ${ }^{45}$ The causative agents are dinoflagellates that contaminate shellfish. Human ingestion of contaminated shellfish may result in poisoning symptoms, including vomiting, diarrhea, asthenia, hypertension, paresthesia, among others. Because high temperatures do not destroy such dinoflagellates or their toxins, the only prevention method is limiting the ingestion of shellfish to that obtained from known, certified dealers, which is duly guaranteed as free of red tide contamination. ${ }^{46}$

Finally, listeriosis, one of the main foodborne diseases, manifests clinically by gastrointestinal disorders, fever, sepsis, meningitis, and miscarriages. Measures to prevent this disease include consumption of only well-cooked meat and pasteurized dairy products, adequate washing of fruits, vegetables, and cooking utensils used for food preparation, as well as meticulous refrigerator cleaning on a regular basis. ${ }^{47}$

\section{Radiation}

Radiation is carcinogenic to humans, particularly to the fetus and the child, by virtue of their high cell division rate, resulting in leukemia, and thyroid, breast, brain and lung neoplasms. Radiation to which children are exposed comes not only from natural sources, such as radon, present naturally in the earth's crust, but also from artificial sources created by man, such as televisions, and also trash and waste generated indoors. ${ }^{2}$

Radon is an odorless, colorless and tasteless inert radioactive gas that originates from the natural breakdown of uranium present in soils and rocks and that moves upwards through the soil; therefore, it occurs in higher concentrations on the lower floors of the buildings. ${ }^{19}$ Radon emits radioactive alpha particles that remain in the air and are subsequently inhaled, building up in the epithelium of the airways. Such particles cause a direct injury to the DNA and may result in lung cancer. Between 5 and $15 \%$ of lung cancer deaths are related to radon exposure, and, in many countries, radon is the second cause of lung cancer, after tobacco. 48

Outdoors, radon is not a major health hazard, because it is diluted in the environment. However, a concentration greater than 4 picocuries per liter of air in a closed environment is a dangerous concentration. High radon concentrations can result from permanent gas penetration through cracks or pores in soil and walls, as well as through openings in foundations, walls, floor joints, pipes, and tubes, among others. ${ }^{19}$

The amount of radon in the air can be measured using two different methods: short-term testing and long-term testing. Testing all homes below the third floor for radon is recommended. Because there is no concentration of radon that is considered to be safe, the U.S. Environmental Protection Agency recommends repairing the home if radon levels are greater than 2 picocuries per liter of air. ${ }^{49}$

In order to reduce radon exposure in homes, it is necessary to optimize the ventilation of the house. Other procedures include sealing cracks in floors and walls, increasing the ventilation of crawl spaces, providing proper insulation, and installing a system to increase air suction in basements. However, the most important preventive measure is to carry out a comprehensive assessment of the real radon emission of the sites on which houses or apartment buildings will be constructed. Measurement of radon levels will provide enough information for taking adequate action. ${ }^{48}$ Additionally, there are techniques for radon-resistant construction, which can be very effective in reducing indoor radon levels. ${ }^{50}$

Radon may also come in the water, causing risk of inhalation and ingestion, and may produce gastric cancer (with low probability). The greatest risk from radon is when it is inhaled after being volatilized from water. The increased risk attributable to radon in the water does not occur in households, but in their ground water sources. ${ }^{18,50}$

\section{Psychosocial factors}

Architectural design of the house may have an impact on the residents' capacity to interact with each other, to 
enjoy privacy, to be able to play, and, mostly, on their ability to develop satisfactorily. A poor architectural design may produce increasing social isolation, as a result of a lack of spaces for interaction, and may increase the risk for mental health disorders and transmissible diseases favored by indoor overcrowding. ${ }^{2}$

Another important environmental factor in childhood psychosocial development is noise. It has been reported that children, when exposed to ambient noise greater than $100 \mathrm{~dB}$, may develop acute terror or panic attacks, and the release of cortisol and an increase in blood pressure may also occur. ${ }^{51}$ Moreover, studies have shown that psychosocial stress may also increase the individual's susceptibility to a variety of pollutants, exacerbating their potential adverse effects. ${ }^{52}$

Additionally, the characteristics of the environment in which children and adolescents live are important factors in their decision whether or not to experiment with drugs, tobacco, and alcohol. Some factors may increase the risk, and others may act in a protective way to prevent experimentation behavior. Instead of trying to convince children that they should avoid any contact with drugs, environmental changes should be made to promote protective factors and reduce risk factors contributing to that behavior. ${ }^{53}$

\section{Pets and domestic animals}

In developing countries such as Chile, many families share their homes with domestic animals, which may transmit diseases by direct contact or through dust and dirt. Anthrax, brucellosis, tuberculosis, listeriosis, salmonellosis, rabies, psittacosis, larva migrans, histoplasmosis, and dermatophytosis are some examples of such disesases. ${ }^{2}$ In addition, pets in the home can worsen asthma and allergic rhinitis. There is a wide range of clinical manifestations of animal allergy. A child may have from mild cutaneous urticaria and rhinoconjunctivitis to severe bronchospasm and anaphylaxis. ${ }^{36,54,55}$ Despite these possible negative effects, pets, in most cases, do provide a benefit in improving mental health.

Animal allergens are glycoproteins that are usually found in saliva and sebaceous glands of cats and dogs, and in the urine of rodents. Allergens may be airborne or attached to various surfaces (e.g. clothes, bedding), and, when inhaled by humans, trigger an IgE response in susceptible individuals. ${ }^{36}$

The most effective measure to control the negative effects of pets is to keep them out of the house. Restricting animal access to bedrooms, keeping the house well-ventilated, and cleaning furniture and carpets on a regular basis are also recommended. ${ }^{56}$ There is evidence that air filtration reduces the levels of allergens from domestic household animals. ${ }^{57}$ Regular bathing of pets is another recommended measure, but this practice is not as effective, because of its short duration. ${ }^{57}$

There is controversy regarding children's exposure to pets. Recent studies suggest that exposure to animals during childhood would be a protective factor, reducing allergic sensitization during adulthood. However, there is agreement that individuals already sensitized should not be exposed to animals. 57

\section{Injury prevention}

Injuries are an important health problem all over the world. Childhood injuries occur at home more often than at school. The leading causes of death in the home are falls, drowning, fires, poisoning, suffocation, and firearms. 58 Although mortality is an important indicator, it should be noted that, for every death, there are thousands of survivors left with disabling sequelae. 59 This fact emphasizes the importance of prevention, which should take into account the specific characteristics of children and adolescents during their development.

Children are constantly involved in tireless activity, and are characterized by their curiosity and exploratory impulses, which makes them more susceptible to poisoning and trauma. When children are very young, they have more contact with floor surfaces due to crawling, and tend to bring everything, including their hands, to their mouths. ${ }^{60}$ Therefore, attention should be paid to removing any hazardous object from their reach.

To successfully decrease the risk of household accidents, it is critical to act on the child's environment to guarantee his/ her health. Additionally, children should always be supervised by a responsible adult. Parents should consistently aim at a balance that enables the child to explore the environment while being safe. ${ }^{61}$

The "four Rs" of poisoning prevention have been described with the purpose of educating parents: 1) Recognize potential poisoning hazards at home; 2) Remove poisonous products; 3) (Be) Ready to act if a poisoning event occurs; and 4) Respond appropriately to a poisoning event. ${ }^{62}$

One of the mainstays of prevention is active inspection of household safety conditions. Various toxic elements may be available to children. Among them, there are several chemical products, such as household cleaning products, medications, and insecticides.

Contact with pyrethroid insecticides may produce hypersensitivity reactions, including dermatitis, asthmatic attacks, and anaphylactic shock. Other pesticides, such as organophosphate insecticides or carbamates, may produce vomiting, nausea, asthenia, vertigo, headache, and, in high doses, tremor, ataxia, seizures, and cardiorespiratory arrest, in the event of being ingested. ${ }^{63}$ It is important to emphasize that, after being applied, insecticides may 
remain on the surface of toys, furniture, and carpets, undergoing volatilization with time. Pesticides may be linked to endocrinological and behavioral disorders, cancer, and immune-system injuries. ${ }^{2}$

Medications are another significant source of poisoning, especially in children under 5 years old. ${ }^{64-66}$ Among them, the most commonly related to environmental pediatrics are benzodiazepines and antidepressant drugs. 67

To prevent poisoning, expiration dates of drugs should be checked on a regular basis. Additionally, toxic agents should be kept in a locked container, in their original packaging, out of the sight and reach of children. The storage of potentially toxic agents below $150 \mathrm{~cm}$ from the floor has 16 times more risk for childhood poisoning than storage at higher heights. ${ }^{68}$

In case of poisoning, it is recommended that parents call the local Poison Control Center immediately. These centers offer professional medical advice and triage designed to treat and reduce the deleterious effects of poisoning. It is important that parents or caregivers provide the following information about the patient: age and weight of the person, the product brand, product class, product content, amount ingested, route of exposure, how long the person was in contact with poison, and how the patient had been helped. 58 Keeping the telephone number of the Poison Control Center of your city or country always visible or easily accessible is recommended.

Injuries occurring inside the house are generally related to poor architectural design, poor quality of building materials, poor maintenance or inappropriate use of household appliances, together with the lack of adequate child supervision. ${ }^{2}$

As children grow, they commonly climb and, because of that, are exposed to falls; therefore, energy-absorbing surfaces are important elements to have both indoors and outdoors. ${ }^{60}$ To prevent falls, it is recommended to keep the floor clear of items that could cause stumbling, especially in corridors and stairways. It is also important to keep the house well illuminated.

Window safety nets are recommended for two-story (or more) houses or buildings, if there are children under 10 years of age. Safety stair gates and safety guards across entries to balconies and across doors, restricting access to the kitchen, are also recommended. ${ }^{9}$

Children under 4 years old are those most likely to die from choking. The most common cause is the presence of foreign bodies in the airways, such as food scraps, buttons or coins. In addition, children may suffer suffocation by being trapped in sheets, blankets or plastic bags. ${ }^{58}$ As a precaution, children under 4 years old should not eat hard candy, peanuts, walnuts, or other foods that could be easily aspirated. ${ }^{58}$ Furthermore, pediatricians should educate parents about the risks for children associated with playing with balloons, bags, coins, marbles, or toys with small parts or buttons.

Drowning is another major cause of childhood deaths worldwide. Children under 5 years old have the highest drowning mortality rates. ${ }^{59}$ Moreover, it has been reported that, for every child who dies from drowning, another 20 are near-drowned. As a precaution, parents should never leave the child unattended in the bathtub, because the child could drown in even a few inches of water. ${ }^{58}$ If there is a swimming pool, it should be surrounded by an isolation fence, which should be not-climbable, measuring at least $1.5 \mathrm{~m}$ in height, with an access door, and a safety lock appropriately located far from the reach of children. ${ }^{58,69}$ If a drowning occurs, the child must be removed immediately from the water and placed on a flat surface; furthermore, cardiopulmonary resuscitation maneuvers (CPR) must be started, and an ambulance called. Older children and adults should learn CPR. Classes are generally offered by the Red Cross. 58

Another source of injury is fire, which is still one of the main causes of death at home, despite the fact that the number of people who die in fires has decreased over the last decade. ${ }^{58}$ Playing with fire (matches, lighters, stoves or heaters) is the leading cause of fire among children under 5 years old. ${ }^{58}$ To prevent fire at home, these items should be stored in a safe place, where children cannot reach them, and stoves should be located out of the passageways and at a distance over $90 \mathrm{~cm}$ from flammable objects. Children should be taught about the escape route from their home in case of fire.

\section{Home construction}

Besides the architectural design and the protective measures intended to prevent household injuries, there are other important variables that can affect the environment, and, therefore, children's health.

One of them is dampness, which may promote the growth of many harmful agents, particularly of molds. Indoor dampness is not only related to climate conditions, but also to poor design and to construction providing poor ventilation. The most vulnerable household areas are the bathroom and the kitchen. Children may suffer asthma, bronchitis, alveolitis, fever, fatigue, cough, and wheezing from the dampness. Among the mitigation measures are frequent ventilation, appropriate cleaning, and avoidance of agents that generate household dampness. ${ }^{2}$

Electric power, directly linked to the degree of development of countries, has enabled a significant improvement in human quality of life. However, it represents a latent hazard to children, when it is within their reach, and they are unsupervised. Electric power may cause burns, wounds, and even death. Electrical injuries results from contact with a source of electrical current or from arcing 
of current near the body. Electrical injury usually produces a depressed entry wound and an exit wound that appears "blown out." With high-voltage currents, defined as more than $1,000 \mathrm{~V}$, the damage to deep tissue is more severe than the appearance of the cutaneous burn indicates. There is evidence that the risk of fatal injuries increases exponentially for voltages over $600 \mathrm{~V}$. Alternating current is usually considered more dangerous than direct current, because muscles may not relax, and the child cannot let go, which increases contact time and results in more severe injury.

In the United States, the number of people requiring emergency care service for electrical injuries is estimated to be approximately 17,000 people per year. Among them, between 1,500 to 3,000 require treatment in a specialized burn center. ${ }^{70}$ Children injured as a consequence of exposure to electrical cables and electrical devices represent $20 \%$ of this population. 70

This is why it is important to isolate sockets and electric appliances, and also to consistently supervise children from the moment they start moving around. The use of extension cords is discouraged, due to the risk of electrocution. ${ }^{66}$

Electric power generates electric and magnetic fields that have been implicated as probable carcinogenic factors for humans; in children, they might be related to leukemia. ${ }^{71}$

Poor architectural design and construction of homes may favor some vector-borne diseases, such as Chagas disease, malaria, and dengue. ${ }^{2}$ Incompletely lined ceilings or walls may favor vector proliferation, as can the use of soil, wood, and bamboo as structural elements. Finally, poor cleaning and inadequate sanitization favor the presence of other disease vectors such as ticks and fleas.

\section{Noise}

Noise is undesirable sound. Environmental noise is clearly a key factor to consider in health. Children are more vulnerable than adults, because they are at higher risk of increased exposure to noise, due to their inherent behaviors. Children may experience learning difficulties, impaired speech development, impaired concentration, hearing loss, and tinnitus as a result of noise exposure. Noise can also cause a stress response, characterized by headache, tiredness, and irritability; in addition, it contributes to sleep deprivation and undesirable cardiovascular effects. ${ }^{52,72}$

Some preventive measures to reduce the deleterious effects of noise are avoiding noisy toys, reducing the volume of televisions and radios, and using earplugs if necessary. ${ }^{72}$

It has been reported in the literature that in utero exposure to noise increases the frequency of deafness in the newborn. Additionally, this exposure is associated with prematurity and intrauterine growth retardation. ${ }^{72}$
Besides keeping household noise at safe levels, design and construction enabling good isolation from outdoor noise is also important. 73

\section{Conclusions}

Numerous factors that make children more vulnerable than adults to environmentally caused injuries have been described. Moreover, it has been shown that the household is a key environment, where children spend almost $90 \%$ of their time. Awareness of the various potentially dangerous household conditions and situations to which children may be exposed should be promoted among caregivers. Understanding the noxious effects of such conditions and knowing about available prevention measures will result in timely and adequate interventions, which will certainly improve our children's health and development.

Concern about environmental health is mandatory both within families and within the community. Thus, the pediatric health team should pay special attention to people's needs, and provide information and education to parents and teachers, to the full community, and even to the authorities, about potential risk situations. $2,9,74$

Nowadays, pediatricians are challenged to address pediatric environmental health care needs. The pediatric health history needs to be more comprehensive by adding accurate questions to help identify potential environmental risks. Some of these questions are: "Where does the child live or spend time?," "Does anyone in the home smoke?," "Do you use well water? Tap water?," "Is there exposure to allergens from items in the diet?," "What do parents/ teenagers do for their living?"75

The pediatrician must know the influence of the environment on children's growth and development, given their particular vulnerability. Therefore, the pediatrician plays a fundamental role on the health team, due to the importance of preventive medicine, and of social and educational involvement. For these reasons, it is essential that courses in pediatrics include environmental health training in their curriculum, strengthening the new preventive paradigm. 76,77

Health monitoring generates a unique opportunity for providing support to the family, while it reinforces and strengthens parents' capacities to respond adequately and safely to their children needs. Considering that injuries are a major public health problem and are mostly preventable, pediatricians should devote special time during health supervision to discuss injury prevention measures with parents. ${ }^{78}$ It has been reported that the promotion of a healthy environment by the pediatrician contributes to lower childhood morbidity and mortality from trauma and poisoning, among other causes. ${ }^{79}$

Diverse diseases caused by environmental factors should always be considered during differential diagnoses. 
The pediatrician should be in continuous professional development, with ongoing training, a critical attitude, and application of state-of-the-art knowledge. ${ }^{79}$ This attitude will facilitate adequate history taking, and a well-oriented physical exam based on proper clinical suspicion.

Over the last decade, some developed countries have created PEHSUs composed of multidisciplinary specialized teams. Counseling, treatment, and research promotion are among the multiple tasks performed by these units. One of the most important responsibilities is public education about the environment and its risks, which should be provided to professionals and to the lay public. ${ }^{6}$ In the coming years, it is expected that more countries will create PEHSUs that will facilitate finding solutions for environmental-hazard derived problems. Children have the right to live and develop, carrying out their activities in a safe environment. Healthcare professionals should be prepared to promote the conditions favoring adequate development and a healthy life.

\section{References}

1. Ordóñez GA. Salud ambiental: concepto y actividades. Rev Panam Salud Publica. 2000;7:137-47.

2. Chaudhuri N, Fruchtengarten L. Where the child lives and plays: A Resource Manual for the Health Sector. In: Pronczuk-Garbino J, editor. Children's health and the environment: A Global Perspective. Geneva: World Health Organization; 2005. p. 26-39.

3. California Childcare Health Program. Salud Ambiental. 2006. http://www.ucsfchildcarehealth.org/pdfs/Curricula/CCHA/17_ CCHA_SP_EnvironHealth_0606_v3.pdf. Access: 04/08/2010.

4. Organización Mundial de la Salud. El medio ambiente y la salud de los niños. http://www.who.int/mediacentre/factsheets/fs284/ es/index.html. Access: 04/08/2010.

5. Paulson JA, Gitterman BA. Children's health and the environment: part II. Pediat Clin North Am. 2007;54: 213-424.

6. Paris M E, Bettini M, Molina H, Mieres JJ, Bravo V, Ríos JC. La importancia de la salud ambiental y el alcance de las unidades de pediatría ambiental. Rev Med Chile. 2009;137:101-5.

7. World Health Organization. Principles for Evaluating Health Risks in Children Associated with Exposure to Chemical (Environmental Health Criteria No 237). Geneva: WHO Press; 2006. http:// www.who.int/entity/ipcs/publications/ehc/ehc237.pdf. Access: 04/08/2010.

8. Chaudhuri N. Interventions to improve children's health by improving the housing environment. Rev Environ Health. 2004; 19:197-222.

9. Paes CE, Gaspar VL. As injúrias não intencionais no ambiente domiciliar: a casa segura. J Pediatr (Rio J). 2005;81:S146-54.

10. Paulson JA, Karr CJ, Seltzer JM, Cherry DC, Sheffield PE, Cifuentes $\mathrm{E}$, et al. Development of the pediatric environmental health specialty unit network in North America. Am J Public Health. 2009;99 Suppl 3:S511-6.

11. Ortega García JA, Ferrís i Tortajada J, López Andreu JA. Paediatric environmental health speciality units in Europe: integrating a missing element into medical care. Int J Hyg Environ Health. 2007;210:527-9.

12. Gil SM. Children environmental health: a new challenge for pediatricians. Arch Argent Pediatr. 2008;106:458-61.
13. Goldman L, Falk H, Landrigan PJ, Balk SJ, Reigart JR, Etzel RA. Environmental pediatrics and its impact on government health policy. Pediatrics. 2004;113:1146-57.

14. Gait N, Pieroto M. Contaminación y contaminantes del Agua. In: Ministerio de Salud Gobierno de Chile, Ministerio de Salud Gobierno de Argentina, Organización Panamericana de la Salud, editors. Manual de Salud Ambiental Infantil para enseñanza de grado en Escuelas de Medicina. Santiago: LOM Ediciones; 2009. p. 56-59.

15. Federación Internacional de Sociedades de la Cruz Roja y de la Media Luna Roja. Iniciativa Global de Agua y Saneamiento. 2004. http://www.cruzroja.org/documentos/docs/Iniciativa_Global20_ Agua_Saneamiento.pdf. Access: 04/08/2010.

16. Organización Mundial de la Salud (OMS). Guías para la calidad del agua potable. Geneve: OMS; 2006. http://www.who. int/water_sanitation_health/dwq/gdwq3_es_fulll_lowsres.pdf. Access: 04/08/2010.

17. Boonyakarnkul T, Kingston PA, Shea KM. Water Quality. In: Pronczuk-Garbino J, editor. Children's health and the environment: A Global Perspective. Geneva: World Health Organization; 2005. p. 71-94.

18. American Academy of Pediatrics Committee on Environmental Health. Water Pollutants. In: Etzel RA, Balk SJ, editors. Pediatric Environmental Health. 2nd ed. Elk Grove Village, IL: American Academy of Pediatrics; 2003. p. 393-415.

19. Moreno LB. Contaminación y contaminantes del Aire Interior. In: Ministerio de Salud Gobierno de Chile, Ministerio de Salud Gobierno de Argentina, Organización Panamericana de la Salud, editors. Manual de Salud Ambiental Infantil para enseñanza de grado en Escuelas de Medicina. Santiago: LOM Ediciones; 2009. p. 67-77.

20. American Academy of Pediatrics Committee on Environmental Health. Carbon Monoxide. In: Etzel RA, Balk SJ, editors. Pediatric Environmental Health. 2nd ed. Elk Grove Village, IL: American Academy of Pediatrics; 2003. p. 113-124.

21. Paris E. Monóxido de carbono. In: Paris E, Ríos JC, editors. Intoxicaciones: Epidemiología, Clínica y Tratamiento. Santiago: Ediciones Universidad Católica de Chile; 2005. p. 281-283.

22. Flanagan RJ, Rooney C. Recording acute poisoning deaths. Forensic Sci Int. 2002;128:3-19.

23. Singh $\mathrm{H}$, Aggarwal $\mathrm{S}$. Carbon monoxide poisoning. Indian J Crit Care Med. 2010;14:105.

24. Mehta S, Shahpar C. The health benefits of interventions to reduce indoor air pollution from solid fuel use: a cost-effectiveness analysis. In: WHO-CHOICE, editor. Energy for Sustainable Development. Geneva: World Health Organization. 2004;8:53-9.

25. Colegio Médico de Chile A.G., Colegio de Ingenieros A.G. Diagnóstico y propuesta conjunta de Colegio Médico de Chile y del Colegio de Ingenieros de Chile para desarrollar una política nacional de energía que favorezca a la salud, el medio ambiente y la economía nacional. Cuadernos Médico Sociales. 2006;46:163-75.

26. American Academy of Pediatrics Committee on Environmental Health. Environmental Tobacco Smoke and Smoking Cessation. In: Etzel RA, Balk SJ, editors. Pediatric Environmental Health. 2nd ed. Elk Grove Village, IL: American Academy of Pediatrics; 2003. p. 147-63.

27. Organización Panamericana de la Salud, Chile. Tabaco. 2007. http://new.paho.org/chi/index.php?option=com_content\&task $=$ view\&id=173\&Itemid=259. Access: 04/08/2010.

28. World Health Organization. Passive Smoking. In: World Health Organization. The tobacco atlas; 2002. http://www.who.int/ tobacco/en/atlas10.pdf. Access: 04/08/2010.

29. Prietsch SO, Fischer GB, Cesar JA, Fabris AR, Mehanna H, Ferreira $\mathrm{TH}$, et al. Doença aguda das vias aéreas inferiores em menores de cinco anos: influência do ambiente doméstico e do tabagismo materno. J Pediatr (Rio J). 2002;78:415-22.

30. Organización Mundial de la Salud. ¿Por qué el tabaco es una prioridad de salud pública? http://www.who.int/tobacco/health_ priority/es/index.html. Access: 19/11/2010. 
31. Fernández RA. Algunos Contaminantes destacados: Intoxicación por plomo en niños. In: Ministerio de Salud Gobierno de Chile, Ministerio de Salud Gobierno de Argentina, Organización Panamericana de la Salud, editors. Manual de Salud Ambiental Infantil para enseñanza de grado en Escuelas de Medicina. Santiago: LOM Ediciones; 2009. p. 119-25.

32. Carvalho FM, Neto AM, Peres MF, Gonçalves HR, Guimarães GC, Amorim CJ, et al. Intoxicação pelo chumbo: Zinco protoporfirina no sanguede crianças de Santo Amaro da Purificação e de Salvador, BA. J Pediatr (Rio J). 1996;72:295-8.

33. Paris Mancilla E. Plomo. In: Paris Mancilla E, Ríos Bustamante JC, editors. Intoxicaciones: Epidemiología, Clínica y Tratamiento. Santiago de Chile: Ediciones Universidad Católica de Chile; 2005. p. 283-7.

34. U.S., Department of Housing and Urban Development. Plomo. In: U.S. Department of Housing and Urban Development, editors. Contribuya a tener un hogar sano. Alabama: Alabama Cooperative Extension System; 2007. p. 29-32.

35. Koburger T, Pitts D, Kramer A. Results of a field study on the influence of HygienicWood mattress toppers on the number of mites in bed dust and the state of health of people with house dust mite allergies. GMS Krankenhhyg Interdiszip. 2010;5:1-9. http://www. wilms.com/Hygiene/Forschungen/MilbenstudieGMSKramerEn.pdf. Access: 01/12/10.

36. American Academy of Pediatrics Committee on Environmental Health. Asthma. In: Etzel RA, Balk SJ, editors. Pediatric Environmental Health. 2nd ed. Elk Grove Village, IL: American Academy of Pediatrics; 2003. p. 523-47.

37. U.S., Department of Housing and Urban Development. Asma y Alergias. In: U.S. Department of Housing and Urban Development, editors. Contribuya a tener un hogar sano. Alabama: Alabama Cooperative Extension System; 2007. p. 11-6.

38. U.S., Department of Housing and Urban Development. Moho y Humedad. In: U.S. Department of Housing and Urban Development, editors. Contribuya a tener un hogar sano. Alabama: Alabama Cooperative Extension System; 2007. p. 17-22.

39. Mahoney DB. Moy GC. Foodborne hazards of particular concerne for the young. In: Pronczuk-Garbino J, editor. Children's health and the environment: A Global Perspective. Genova: World Health Organization; 2005. p. 133-52.

40. Organización Mundial de la Salud (OMS). Manual sobre las cinco claves para la inocuidad de los alimentos. Ginebra: OMS; 2007. http://whqlibdoc.who.int/publications/2006/9789243594637_ spa.pdf. Access: 04/08/2010.

41. Morais T, Sigulem D. Efeito da fervura doméstica e da refrigeração na carga bacteriana do leite pasteurizado tipo C. J Pediatr (Rio J). $2000 ; 76: 357-60$.

42. Food and Agriculture Organization. Evaluación de Riesgos de Vibrio spp. en pescados y mariscos. http://www.fao.org/docrep/008/ y8145s/y8145s08.htm. Access: 20/11/10.

43. Dabanch P J, Herrero C D, Pavéz A C, Veas P N, Braun J S, Porte T L. Bacteriemia por Vibrio parahaemolyticus: Reporte de caso y revisión de la literatura. Rev Chilena Infectol. 2009;26:360-2.

44. Chile, Ministerio de Salud, Departamento de Epidemiología. Gastroenteritis por Vibrio Parahaemolyticus. http://epi.minsal.cl/ epi/html/public/Vparahaemolyticus.htm. Access: 04/08/2010.

45. Elizabeth K, Gopakumar H, Koshy G. Red Tide Phenomenon Leading to Panic Attack and Mass Casualty among Children in Coastal Kerala. Indian J Community Med. 2010;35:342-3.

46. Chile, Ministerio de Salud, Departamento de Epidemiología. Información al Viajero, Enfermedades Infecciosas y su Prevención; 1998. http://epi.minsal.cl/epi/html/enfer/veranosalud.html. Access: 04/08/2010.

47. Chile, Ministerio de Salud. Informe Listeriosis, 08 Febrero 2010. http://epi.minsal.cl/epi/html/bolets/reportes/Listeriosis/Informe \%20brote\%20Listeria.pdf. Access: 04/08/2010.

48. Organización Mundial de la Salud. Notas Descriptivas - El Radón y El Cáncer. http://www.who.int/mediacentre/factsheets/fs291/ es/index.html. Access: 04/08/2010.
49. Children's Environmental Health Network. Programa Sobre Ambientes Saludables Para Niños y Prescolares 2009: Radón. http://www.cehn.org/files/Radon.pdf. Access: 19/11/2010.

50. United States Environmental Protection Agency. Publications - A Citizen's Guide to Radon. http://www.epa.gov/radon/pubs/ citguide.html\#El_Rad\%C3\%B3n. Access 20/11/10.

51. Bearer CF. Noise. In: Pronczuk-Garbino J, editor. Children's health and the environment: A Global Perspective. Geneva: World Health Organization; 2005. p. 194-201.

52. Adler T. Una relación compleja: estrés psicosocial, contaminación y salud. Salud Pública Méx. 2009;51:524.

53. Monteiro M. When the child uses alcohol and other drugs. In: Pronczuk-Garbino J, editor. Children's health and the environment: A Global Perspective. Geneva: World Health Organization; 2005. p. 64-67.

54. Bertrand $P$, Contreras I. Asma Bronquial: Tratamiento. In: Sánchez I, Prado F, editors. Enfoque Clínico de las Enfermedades Respiratorias del Niño. Santiago: Ediciones Universidad Católica de Chile; 2007. p. 209-228.

55. Moraes LS, Barros MD, Takano OA, Assami NM. Fatores de risco, aspectos clínicos e laboratoriais da asma em crianças. J Pediatr (Rio J). 2001;77:447-54.

56. Agencia de Protección Ambiental de los Estados Unidos, División de Ambientes Interiores, Oficina de Aire y Radiación. Ayude a su niño a controlar el asma: Las mascotas; 2005. http://www.epa.gov/iaq/schools/pdfs/publications/II_asthma_ brochure_sp.pdf. Access 01/12/10.

57. Baxi SN, Phipatanakul W. The role of allergen exposure and avoidance in asthma. Adolesc Med State Art Rev. 2010;21:57-71, viii-ix.

58. U.S. Department of Housing and Urban Development. Seguridad en el Hogar. In: U.S. Department of Housing and Urban Development, editors. Contribuya a tener un hogar sano. Alabama: Alabama Cooperative Extension System; 2007. p. 48-54.

59. Guthrie T, McGee K, Thein MM. Unintentional injuries in children. In: Pronczuk-Garbino J, editor. Children's health and the environment: A Global Perspective. Geneva: World Health Organization; 2005. p. $177-186$.

60. Mello-da-Silva CA, Fruchtengarten L. Riscos químicos ambientais à saúde da criança. J Pediatr (Rio J). 2005;81:205-11.

61. Valenzuela PM. Segundo Año de Vida: Quince Meses. In: Catalán S, editor. La Supervisión de Salud del Niño y del Adolescente. Santiago: Editorial Mediterráneo; 2000. p. 96-9.

62. Makalinao I, Woolf AD. Poisonings and envenomings. In: PronczukGarbino J, editor. Children's health and the environment: A Global Perspective. Geneva: World Health Organization; 2005. p. 153-176.

63. Ríos JC. Guía de Intoxicaciones CITUC: Piretrinas y Piretroides. Santiago: Pontificia Universidad Católica de Chile. http://escuela. med.puc.cl/publ/guiaintoxicaciones/piretrinas.html. Access: 04/08/2010.

64. Gaspar VL, Lamounier JA, Cunha FM, Gaspar JC. Fatores relacionados a hospitalizações por injúrias em crianças e adolescentes. J Pediatr (Rio J). 2004;80:447-52.

65. Blank D. Prevenção e controle de injúrias físicas: saímos ou não do século 20? J Pediatr (Rio J). 2002;78:84-6.

66. Baracat EC, Paraschin K, Nogueira RJ, Reis MC, Fraga AM, Sperotto G. Acidentes com crianças e sua evolução na região de Campinas, SP. J Pediatr (Rio J). 2000;76:368-74.

67. Centro de Información Toxicológica (CITUC). Estadísticas CITUC - Casos de Intoxicaciones por categorías de agente y edad; 2007. http://www.cituc.cl/files/arc/ci_estadisticas / 6857278824b26b0d8d586e.pdf. Access: 04/08/2010.

68. Ramos CL, Barros HM, Stein AT, da Costa JS. Risk factors contributing to childhood poisoning. J Pediatr (Rio J). 2010;86:435-40.

69. American Academy of Pediatrics Committee on Injury, Violence, and Poison Prevention. Prevention of drowning in infants, children, and adolescents. Pediatrics. 2003;112:437-9. 
70. Rodriguez MA, Marchesse M. Lesiones por electricidad. Santiago: Pontificia Universidad Católica de Chile; 2001. http://escuela. med.puc.cl/publ/TemasMedicinaInterna/electricidad.html. Access: $21 / 11 / 10$.

71. World Health Organization, International Agency for Research on Cancer (IARC). Case-control studies: Leukemia. In: World Health Organization, International Agency for Research on Cancer (IARC), editors. IARC Monographs on the Evaluation of Carcinogenic Risks to Humans. Volume 80: Non-ionizing radiation, Part 1: Static and extremely low frequency (ELF) electric and magnetic fields. Lyon: IARC Press; 2002. p. 194-219. http://monographs.iarc. fr/ENG/Monographs/vol80/mono80.pdf. Access: 04/08/2010.

72. American Academy of Pediatrics Committee on Environmental Health. Noise. In: Etzel RA, Balk SJ, editors. Pediatric Environmental Health. 2nd ed. Elk Grove Village, IL: American Academy of Pediatrics; 2003. p. 311-321.

73. Roche AF, Siervogel RM, Himes JH, Johnson DL. Longitudinal study of hearing in children: baseline data concerning auditory thresholds, noise exposure, and biological factors. J Acoust Soc Am. 1978;64:1593-616.

74. Waksman RD. Redução de lesões por causas externas: o pediatra pode intervir? J Pediatr (Rio J). 2004;80:435-6.

75. American Academy of Pediatrics Committee on Environmental Health. How to Take an Environmental History. In: Etzel RA, Balk SJ, editors. Pediatric Environmental Health. 2nd ed. Elk Grove Village, IL: American Academy of Pediatrics; 2003. p. 37-46.
76. Bressan AM. Historia de la Salud Ambiental: Situación Sanitaria y Ambiental de Argentina. In: Ministerio de Salud Gobierno de Chile, Ministerio de Salud Gobierno de Argentina, Organización Panamericana de la Salud, editors. Manual de Salud Ambiental Infantil para enseñanza de grado en Escuelas de Medicina. Santiago: LOM Ediciones; 2009. p. 18-26.

77. Zayas Mujica R, Cabrera Cardenas U. Los tóxicos ambientales y su impacto en la salud de los niños. Rev Cubana Pediatr. 2007;79:0.

78. Cifuentes L. El registro en la supervisión de salud. In: Catalán S, editor. La Supervisión de Salud del Niño y del Adolescente. Santiago: Editorial Mediterráneo; 2000. p. 31-6.

79. Vargas C NA, Quezada L A. Epidemiología, nueva morbilidad pediátrica y rol del pediatra. Rev Chil Pediatr. 2007;78:103-10.

Correspondence:

Patricia M. Valenzuela

Department of Pediatrics - Pontificia Universidad Católica de Chile Lira, 85 - Santiago Centro

Santiago - Chile

Tel. : +56 (2) 354.3887

Fax: +56 (2) 638.4307

E-mail: pvalenzu@med.puc.c 